\title{
Study of Serpentinized Ultramafic Rocks of Bela Ophiolite, Balochistan, Pakistan
}

\author{
Erum Bashir \\ Department of Geology, University of Karachi, Karachi 75270, Pakistan \\ E-mail: ebahmed@yahoo.com \\ Shahid Naseem (Corresponding author) \\ Department of Geology, University of Karachi, Karachi 75270, Pakistan \\ Maria Kaleem \\ Department of Geology, University of Karachi, Karachi 75270, Pakistan \\ E-mail: maaria_kaleem@yahoo.com \\ Yousuf Khan \\ Centralize Lab, Faculty of Science, University of Karachi, Karachi 75270, Pakistan \\ E-mail: yousufkhanaph@gmail.com
}

Salma Hamza

Department of Geology, Federal Urdu University of Arts, Science and Technology, Karachi, Pakistan E-mail: salma_great@yahoo.com

Received: October 24, 2011 Accepted: November 4, $2011 \quad$ Published: March 1, 2012

doi:10.5539/jgg.v4n1p79 URL: http://dx.doi.org/10.5539/jgg.v4n1p79

\begin{abstract}
Mineralogical and petrological study of ultramafic rocks of Bela Ophiolite of Cretaceous age revealed serpentinization after harzburgite. It is further evident on $\mathrm{SiO}_{2} / \mathrm{MgO}$ vs. $\mathrm{Al}_{2} \mathrm{O}_{3}$, molar ratio $\mathrm{Si} / \mathrm{Mg}+\mathrm{Fe}$ vs. $\mathrm{LOI}$ and $\mathrm{MgO}-\mathrm{SiO}_{2}$-LOI diagrams. The XRD analysis also showed occurrence of olivine, different members of pyroxene and serpentine groups. The three polymorphous of serpentines can be distinguished on $\left(\mathrm{Fe}^{2+}+\right.$ $\left.\mathrm{Mg}^{2+}\right) /\left(\mathrm{Fe}^{3+}+\mathrm{Al}^{3+}\right)$ vs. $\mathrm{H}_{2} \mathrm{O}$ diagram, reflecting thermal regime in the study area.

The analyzed samples of the study area showed relevance with Alpine peridotites. The plots $\mathrm{MgO}$ versus CaO and $\mathrm{Ni}$ show relation with average primitive mantle. The high amount of $\mathrm{Ni}$ and low content of $\mathrm{Al}_{2} \mathrm{O}_{3}$ in the study area indicates depleted-mantle peridotite. The parent rock is classified on the basis of $\mathrm{Al} / \mathrm{Si}$ (av. 0.031) and $\mathrm{Mg} / \mathrm{Si}$ (av. 1.05) ratios as harzburgite. The altered harzburgites displayed as serpentines on $\mathrm{SiO}_{2}$ vs. LOI plot and $\mathrm{SiO}_{2}-\left(\mathrm{Al}_{2} \mathrm{O}_{3}+\mathrm{Fe}_{2} \mathrm{O}_{3}\right)-\mathrm{MgO}$ triangular diagram.
\end{abstract}

Keywords: Serpentinized ultramafic rocks, Geochemistry, Balochistan, Pakistan, Bela Ophiolite

\section{Introduction}

Ophiolites of Pakistan were developed on Neotethys ocean floor prior to the India-Eurasia collision, during Late Cretaceous times. The Bela Ophiolite $(\mathrm{BO})$ is the largest $(\sim 450 \mathrm{~km})$ and most complete ophiolite in Pakistan, striking NS. The BO is linked with Alpine-Himalayan Mesozoic Ophiolite Belt, which stretches from European Alps to Asia.

Ultramafic rocks are formed by eruption from the mantle, by solidification of cumulates from partial crystallization of mafic melts at shallow depths, and by exhumation from the mantle through impacts and 
tectonics (Sleep et al., 2004). After their formation, the ultramafic rocks are subjected to intense alteration and low temperature metamorphism beneath the mid oceanic ridge. The hydration process of the mantle (magmatic olivine and pyroxenes) is critical to understanding the physical and chemical consequences of serpentinization on the structure and tectonics of the oceanic crust.

In recent years, serpentinized ultramafic rocks have received considerable attention. It has a number of remarkable geochemical features, such as exceptionally high concentration of fluid-mobile elements (As, Sb, B \& Li), low $\mathrm{O}$ and $\mathrm{S}$ fugacity and high magnetic susceptibility (Deschamps et al., 2009). The process of serpentinization originates varieties of fascinating mineral models. It can host cryptocrystalline magnesite, talc and asbestos deposits (Simandl and Ogden, 1999); Brucite, (Antonio and Kristensen, 2004); un-usual nickel minerals and hydrogarnet (Frost and Beard, 2007). During the process of serpentinization, platinum group elements may also concentrates in sulfide ore complexes (Palandri and Reed, 2004). Present studies highlighted the petrology, mineralogy and geochemistry of serpentinized ultramafic rocks and a genetic model is deduced to display process of serpentinization in the study area.

\section{Sampling and Analytical Methods}

Samples of serpentinized ultramafic rocks of BO were collected from eighteen different locations (Figure 1). The pulverized rock samples were fused with lithium metaborate in a platinum crucible. Silica $\left(\mathrm{SiO}_{2}\right)$ was estimated gravimetrically using hydrofluoric (HF) acid. The chemical composition of major and trace elements were determined by an atomic absorption spectrophotometer (Hitachi Model, Z 5000).

$\mathrm{X}$-ray analysis of rock samples were carried out using a Bruker AXS $5000 \mathrm{X}$-ray diffractometer. $\mathrm{Cu}, \mathrm{K} \alpha$ radiation was used during the analysis. Thin sections of relatively fresh ultramafic rocks were studied using Laborlus Pols microscope and photographed on Leica Microsystem, (DFC 280).

\section{General Geology}

The study area lies within the Western Fold Belt of Pakistan forming the western margin of the Indian plate. The belt comprises of $\mathrm{BO}$ and sedimentary rocks ranging in age from Jurassic to Tertiary. On the basis of thick crustal sequence, absence of dolerite dykes in the mantle sequence, presence of cumulate gabbros and large quantities of podiform chromite, the BO exhibits relevance with HOT-type ophiolite of Nicolas (1989). Gnos et al. (1998) divided BO into upper (northern) and lower (southern) units on the basis of age difference and emplacement style. Upper unit of BO is presented by true ophiolitic sequence, carries typical island arc lithologies including low-Ti mafic rocks (Sheth, 2008). The lower unit comprises of tectonic accretionary wedge of older back-arc basin lithologies, including high-Ti mafic rocks.

Yaliniz et al. (1996) have divided the ophiolites of the region into two groups; western MOR Jurassic and eastern suprasubduction (SSZ) Cretaceous ophiolites. The SSZ features often comparable with younger back-arc basins worldwide (Pearce et al., 1994). Neotethyan SSZ ophiolites that developed along the periphery of the Mesozoic Gondwanaland represent the remnants of an anomalous oceanic crust produced in a proto-forearc setting (Dilek and Thy, 2009). The BO is originated from obduction of Neotethyan oceanic plate on the rifted western margin of Indian plate (MOR), obducted floor of a back-arc basin (SSZ) and an associated island arc originated in a large oceanic fracture zone (Sheth, 2008 and Yingqian et al., 2008).

\section{Result and Discussions}

\subsection{Petrography}

Petrographic study of the ultramafic rocks of the area is complicated due to alteration. In some relatively unaltered rocks, relics of the original mafic minerals are visible (Figure $2 \mathrm{~A} \& \mathrm{~B}$ ) reflecting the nature of primary rocks. Majority of the studied samples show mesh (Figure 2A) and bastite textures. According to Shervais et al. (2005) mesh texture are developed after olivine while bastite texture formed after the alteration of orthopyroxene (Azer and Khalil, 2005). Samples BN2 and BL1 are fine grained serpentine, sample BN2 possesses few relics of pyroxene phenocrysts showing parallel arrangement of minerals with mesh texture groundmass (Figure 2B) while BL1 exhibits relatively coarse hourglass-mesh texture. Enstatite is identified by the presence of some patchy remnants of yellow relics (Figure 2C). The process of serpentinization was more pronounced over the iron bearing pyroxenes, which is evidenced by the presence of limonitization and hematization. The dominant serpentine mineral in the sample is antigorite with some lizardite.

Sample UE3 is a serpentinized rock and exhibit mesh and fibrous varieties (Figure 2D). The mesh rims form a stockwork of pseudofibrous serpentine in which the fibers of lizardite are aligned perpendicular to the fracture walls. Similar observations were also made by Shervais et al. (2005) while working on chemical study of serpentinization-Stonyford, California, USA. 


\subsection{Mineralogy}

The detail study of altered ultramafic rocks can not be satisfactorily evaluated through polarizing microscope. The mineralogical investigation of these rocks is carried out with the help of XRD and is presented in Table 1, which exhibit olivine, pyroxenes and serpentine minerals. The other mineral like chlorite, feldspars and carbonates are not included.

\subsubsection{Olivine}

Olivine is the dominant mineral of dunite, harzburgite, wehrlite and lherzolite within the domain of peridotites. The olivine is present in seven selected samples of the study area (Table 1) showing variation between 29.8-1.2\%, depending upon the degree of alteration. The highest content is reported in sample KE1 (29.8\%) then in BS1 (27.8\%) while other contains $<10 \%$. Probably most of olivine is readily altered into serpentine minerals.

\subsubsection{Pyroxenes}

The presence of six different pyroxene minerals (Table 1) is good enough to provide thermal history of the area. High temperature enstatite is followed by hypersthene, diopside, hedenbergite and augite. The enstatite is reported from seven different localities. Maximum concentration is found in sample SG1 (60.5\%) and minimum in BL1 (7.6\%). Next common members are augite (24.9-5.5\%), diopside (10.8-4.7\%) and esseneite (11-4\%). The sample GG2 contains all three members in concentrations $24.9,10.8$ and $11 \%$ respectively. Hypersthene is reported in two samples (45.2-35.1\%). Hedenbergite is found only in sample UE3. The pyroxenes are real contributor of $\mathrm{Ca}$ and $\mathrm{Fe}$. Calcium is brought through the diopside between $300-100^{\circ} \mathrm{C}$ because at this temperature range diopside is soluble in serpentinites and the activity of $\mathrm{Ca}^{2+}$ is increases by more than three orders of magnitude (Frost and Beard, 2007).

\subsubsection{Serpentine}

Another important mineral group analyzed in the samples is serpentine; a hydrated magnesium silicate $\left[\mathrm{Mg}_{6} \mathrm{Si}_{4} \mathrm{O}_{10}(\mathrm{OH})_{8}\right]$. It is commonly found in ultramafic rocks like dunites, pyroxenites and peridotites. They are widespread rock-forming minerals that play major role in tectonic processes (Dódony et al., 2002). Serpentines are derived from the low-temperature alteration via cool water circulation that accompanies the ocean floor down into the mantle. They occur on every continent where ocean plate subduction occurred in the past or present.

The serpentinization of olivines and pyroxenes leads to the formation of serpentine group minerals. The formation of lizardite and chrysotile are started at temperature $<350^{\circ} \mathrm{C}$ (Barnes and $\mathrm{O}^{\prime} \mathrm{Neil}, 1969$ ) and are stable under temperatures of $400-440^{\circ} \mathrm{C}$ (Moody, 1976). These serpentine minerals are transformed to antigorite at higher temperatures $\sim 500^{\circ} \mathrm{C}$ (Özkan, 1983-84). In the studied samples, all the three members (antigorite, lizardite and chrysotile) are reported with varying proportions (Table 1). The dominant one is antigorite $(100-25 \%)$ found in nine different localities. The maximum concentration of lizardite is found in sample PK1 (64\%) and minimum in BL1 (23\%) whereas chrysotile varies between $22.5-14 \%$. The mutual association of serpentine minerals depends upon the extent of alteration and temperature condition prevailed in the study area. The temperature trend shows increase towards south (sample GD1). It is also supported by the presence of green schist facies at Sonaro locality (Khan et al., 1999). Other minor trend of increasing temperature is observed towards east of Pahar Khan. Probably, the rise in temperature is due to obduction onto the western margin of Indian Plate. Two separate bodies in the north (Gangu and Ustam Butt) show slight low temperature regime in the area. However, at many localities, serpentine minerals are accompanied with partially unaltered parent rock minerals, reflecting partial serpentinization.

\subsection{Geochemistry}

The analyzed serpentinized peridotites of the study area show a wide variation in $\mathrm{MgO}(20.38-36.81 \%)$ and $\mathrm{CaO}$ $(2.21-14.01 \%)$ as compared to average mantle peridotites $(35-46 \%)$ and $(3.5-4 \%)$ respectively (Palme and O'Neill, 2003). The plots $\mathrm{MgO}$ versus $\mathrm{CaO}$ (Figure 3A) are in an array, showing drift with reference to the average primitive mantle (PM) possibly due to the alterations. The inverse relationship $(r=-0.747)$ exhibits enrichment of $\mathrm{Ca}$ at the expense of Mg. Present studies also get support from the work of Bodinier et al. (2008) while working on the ultramafic rocks of southern Spain. The samples of the study area have high $\mathrm{FeO}$ (av. 7.52\%) with respect to the corresponding $\mathrm{MgO}$ (av. 29.62\%) showing relevance with Alpine peridotites. The Alpine peridotites are characterized by strong compositional heterogeneity, because they face multiple processes including partial melting and melt extraction (Piccardo et al., 2009).

The elements compatible with olivine, such as $\mathrm{Ni}$, increases with increasing $\mathrm{MgO}$ content (Figure 3B) in the studied rocks. However, the plots are scattered with variable Ni concentration as compared to PM. It is also reflected from medium correlation matrix $(r=0.393)$. The high concentrations of $\mathrm{Ni}$ in the rocks reflect their 
development from a depleted-mantle peridotite source (Azer and Khalil, 2005). The $\mathrm{Al}_{2} \mathrm{O}_{3}$ vs. $\mathrm{SiO}_{2} / \mathrm{MgO}$ cross plot is valuable to infer the parent compositions of olivine, orthopyroxene and clinopyroxene in rocks from orogenic peridotites. On the diagram (Figure 4A), the studied samples plotted close to the peridotite. The rocks comprised of low-alumina $\left(\mathrm{Al}_{2} \mathrm{O}_{3}<10 \%\right)$; includes orthopyroxenites containing variable amounts of olivine (Bodinier and Godard, 2003) and very low plagioclases (Sano and Kimura, 2007). The low content of $\mathrm{Al}_{2} \mathrm{O}_{3}$ (av. $0.96 \%$ ) in the study area indicates depleted peridotites which generally formed at more distal (internal, oceanic) settings of the basin, represent refractory residua after asthenosphere partial melting and MORB extraction and to be similar to modern abyssal peridotites (Piccardo et al., 2009). The occurrence of depleted mantle is associated with fast spreading ridges, which favour the formation of most refractory peridotites (Godard et al., 2008). Deschamps et al. (2009) apply $\mathrm{Al} / \mathrm{Si}$ and $\mathrm{Mg} / \mathrm{Si}$ ratios as indicative of the mantle protolith. The calculated ratios $\mathrm{Al} / \mathrm{Si}$ (av. 0.031) and $\mathrm{Mg} / \mathrm{Si}$ (av. 1.05) of the studied samples, signifies harzburgite composition. Melchar et al. (2002) is presented a plot of molar $\mathrm{Si} /(\mathrm{Mg}+\mathrm{Fe})$ vs. LOI to demonstrate possible major element mobility. In general, peridotites are more hydrated than pyroxenites, due to the greater susceptibility to hydration of olivine. In peridotites, $\mathrm{Si} /(\mathrm{Mg}+\mathrm{Fe})$ ranges from 0.5 to 0.7 , reflecting mixtures between olivine $(0.5)$ and orthopyroxene ( 1) and/or clinopyroxene (1-1.3). In the present study, majority of the samples form cluster within the zone of peridotites (Figure 4B). However, no specific trend is seen with increasing LOI, indicating that hydration processes occurred without significant changes of Si-Mg ratios. This may either point to removal of silica or alternatively may be attributed to preferential hydration of olivine compared to clinopyroxene.

\subsection{Serpentinization}

Hydration of harzburgite (olivines+orthopyroxenes) may lead to the formation of serpentine and magnetite (Li et al., 2004). Frost and Beard (2007) and Shervais et al. (2005) further elaborate the alteration mechanism of olivines and orthopyroxenes (Eq. $1 \&$ 2). Additionally, talc (Eq. 3) and magnetite (Eq. 4) are also formed during the serpentinization of olivine (Yalcin and Bozkaya, 2004). The reaction mechanism in the study area favours the allochemical type of serpentinization, in which large positively charged ions such as $\mathrm{Mg}^{+2}, \mathrm{Ca}^{+2}, \mathrm{Fe}^{+2}$ and $\mathrm{Si}^{+4}$, are released into solution (Raymond, 2002). The prevalence of carbonates of $\mathrm{Mg}, \mathrm{Ca}$ and $\mathrm{Fe}$ in the study area promote the idea of allochemical serpentinization in the area.

$$
4 \mathrm{H}_{2} \mathrm{O} \text { (water) }+3 \mathrm{Mg}_{2} \mathrm{SiO}_{4} \text { (olivine) }+\mathrm{SiO}_{2}=2 \mathrm{Mg}_{3} \mathrm{Si}_{2} \mathrm{O}_{5}(\mathrm{OH})_{4} \text { (Serpentine) }
$$

$4 \mathrm{H}_{2} \mathrm{O}$ (water) $+3 \mathrm{Mg}_{2} \mathrm{Si}_{2} \mathrm{O}_{6}$ (orthopyroxene) $=2 \mathrm{Mg}_{3} \mathrm{Si}_{2} \mathrm{O}_{5}(\mathrm{OH})_{4}$ (serpentine) $+2 \mathrm{SiO}_{2}$ (aqueous silica)

$6 \mathrm{Mg}_{2} \mathrm{SiO}_{4}$ (forsterite) $+3 \mathrm{H}_{2} \mathrm{O}=\mathrm{Mg}_{3} \mathrm{Si}_{2} \mathrm{O}_{5}(\mathrm{OH})_{4}$ (serpentine) $+\mathrm{Mg}_{3} \mathrm{Si}_{4} \mathrm{O}_{10}(\mathrm{OH})_{2}$ (talc) $+6 \mathrm{Mg}^{+}$

$3(\mathrm{Mg}, \mathrm{Fe})_{2} \mathrm{SiO}_{4}$ (fayalite) $+3 \mathrm{H}_{2} \mathrm{O}=\mathrm{Mg}_{3} \mathrm{Si}_{2} \mathrm{O}_{5}(\mathrm{OH})_{4}$ (serpentine) $+\mathrm{Fe}_{3} \mathrm{O}_{4}$ (magnetite) $+2 \mathrm{OH}^{-}$

The relations of chemical constituents with degree of serpentinization are conferred in view of above discussion. The LOI is broadly considered to be a measure of the degree of serpentinization. According to Deer et al. (1992) serpentine minerals contain between 12 and $15 \% \mathrm{H}_{2} \mathrm{O}$. It can also be visualized from the graph (Figure 5) which shows increase of LOI with decrease of $\mathrm{SiO}_{2}$ indicating intense serpentinization in the rocks of the study area. Robinson et al. (2006) evaluated serpentinization of the rocks using molar $\mathrm{Si} /(\mathrm{Mg}+\mathrm{Fe})$ vs. $\mathrm{C} /(\mathrm{Mg}+\mathrm{Fe})$. The diagram (Figure 6) exhibit clusters in the area close to antigorite with some influence of talc, reflecting extent of serpentinization. These rocks have a $\mathrm{C} / \mathrm{Mg}+\mathrm{Fe}$ value near 0.4 and increasing $\mathrm{Si} / \mathrm{Mg}+\mathrm{Fe}$ reflecting relative gain in silica and/or relative loss in magnesia.

Ehlers and Blatt (1980) presented an easy approach on $\mathrm{MgO}-\mathrm{SiO}_{2}$-LOI ternary diagram to deduce pathway of serpentinization of ultramafic rocks through chemical component facing immense alteration. The samples of study area occupies field between average serpentine and talc (Figure 7A), indicating that initially they were derived from ultramafic rocks. It is also supported by $\mathrm{SiO}_{2}-\left(\mathrm{Al}_{2} \mathrm{O}_{3}+\mathrm{Fe}_{2} \mathrm{O}_{3}\right)-\mathrm{MgO}$ triangular diagram (Figure 7B), in which the samples of the study area occupied the field of serpentines, as described by Yalcin and Bozkaya (2004). Chemically, the polymorphous of serpentines can be distinguished by the covariation of $\left(\mathrm{Fe}^{2+}+\right.$ $\left.\mathrm{Mg}^{2+}\right) /\left(\mathrm{Fe}^{3+}+\mathrm{Al}^{3+}\right)$ versus $\mathrm{H}_{2} \mathrm{O}$. The antigorite has comparatively low $\mathrm{H}_{2} \mathrm{O}$ and high $\mathrm{SiO}_{2}$; chrysotile is characterized by a relatively high $\mathrm{H}_{2} \mathrm{O}$ and $\mathrm{MgO}$ and small ratio of $\mathrm{Fe}_{2} \mathrm{O}_{3}$ to $\mathrm{FeO}$; while lizardite has high $\mathrm{SiO}_{2}$ and low FeO contents (Page, 1968). The samples of the study area (Figure 8) also show correspondence with the finding of Page (1968). Antigorite along with lizardite is characteristic minerals for continental serpentinization, which formed during syntectonic metamorphism.

\section{Genetic Model}

The BO was formed in the Aptian time ( 70Ma) due to the sea floor rifting in the southern arm of Neotethys Sea. The huzburgite sub-type (peridotite-dunite) mainly developed as a lower most segment of ophiolite due to the fast rate of spreading (Nicolas, 1989). Hydrothermal metamorphism is caused by seawater convective 
currents, circulating at the mid oceanic ridge. In the early phase of alteration, the high Mg-bearing rocks (olivines and pyroxenes) are hydrated. Bosch et al. (2004) modeled hydrothermal alteration related to seawater ingression through variable sized microcracks as in the Oman Ophiolite, which is analogous in many features with BO of Pakistan.

The other phase of serpentinization is related to subduction process, occurred underneath the western margin of Indian Plate between 70-65Ma. With the passage of time, arc volcanism initiated, as indicated by many geoscientists (Sheth, 2008; Yingqian et al., 2008). During the subduction, the mantle wedge is serpentinized accumulating low density muddy slurry, mostly in the fore arc setting forming serpentine mud volcano (Snyder et al., 2005). During the India-Asia collision, BO was obducted cause faulting that creates a number of fractures and cracks in the rock, facilitating water to hydrate the olivines and pyroxenes at mass level. The last episode of serpentinization occurs after the completion (40Ma) of obduction (Gnos et al., 1998). This resulted, development of grid pattern in the ultramafic rocks.

\section{Conclusions}

Petrology and mineralogy reveals that the studied rocks are serpentinites after harzburgite containing variable proportions of olivine and pyroxene. Petrographically, the serpentinized rocks of the study area show mesh and bastite textures after alteration of olivine and orthopyroxene. The XRD studies reveals variable concentration of olivine (29.8-1.2\%), along with pyroxenes; enstatite (60.5-7.6\%), hypersthene (45.2-35.1\%), diopside (10.8-4.7\%), augite (24.9-5.5\%), esseneite (11-4\%) and hedenbergite (9.9\%). Antigorite is one of the most common serpentine mineral, while lizardite and chrysotile are also associated with variable proportion. The three polymorphous of serpentines can also be distinguished on $\left(\mathrm{Fe}^{2+}+\mathrm{Mg}^{2+}\right) /\left(\mathrm{Fe}^{3+}+\mathrm{Al}^{3+}\right)$ vs. $\mathrm{H}_{2} \mathrm{O}$ diagram.

The $\mathrm{MgO}$ vs. $\mathrm{CaO}$ and $\mathrm{MgO}$ vs. $\mathrm{Ni}$ demonstrate relationship with average composition of primative mantle peridotites. The high $\mathrm{FeO}$ (av. 7.52\%) with respect to the corresponding $\mathrm{MgO}$ (av. 29.62\%) values shows relevance with Alpine peridotites whereas high $\mathrm{Ni}$ and low content of $\mathrm{Al}_{2} \mathrm{O}_{3}$ reflects their development from a depleted-mantle peridotite generally formed at more distal settings of the basin. In the study area, the parent rock is classified on the basis of ratios $\mathrm{Al} / \mathrm{Si}$ (av. 0.031) and $\mathrm{Mg} / \mathrm{Si}$ (av. 1.05) as harzburgite. The parent rock composition further witnessed for olivine and orthopyroxenes on $\mathrm{SiO}_{2} / \mathrm{MgO}$ vs. $\mathrm{Al}_{2} \mathrm{O}_{3}$ and molar ratio $\mathrm{Si} / \mathrm{Mg}+\mathrm{Fe}$ vs. LOI diagrams.

The rocks of the study area on LOI vs. $\mathrm{SiO}_{2}$ and $\mathrm{SiO}_{2}-\left(\mathrm{Al}_{2} \mathrm{O}_{3}+\mathrm{Fe}_{2} \mathrm{O}_{3}\right)-\mathrm{MgO}$ diagram occupies the field of serpentines. The study of serpentinization of ultramafic rocks of the area can be visualized on $\mathrm{MgO}-\mathrm{SiO}_{2}-\mathrm{LOI}$ and $\mathrm{Si} /(\mathrm{Mg}+\mathrm{Fe})$ vs. $\mathrm{C} /(\mathrm{Mg}+\mathrm{Fe})$ diagrams. The studied serpentines are derived from olivine and orthopyroxenes via anthophyllite and talc.

\section{References}

Antonio, M. D. \& Kristensen, M. B. (2004). Serpentine and brucite of ultramafic clasts from the South Chamorro Seamount (Ocean Drilling Program Leg 195, Site 1200): inferences for the serpentinization of the Mariana forearc mantle. Mineralogical Magazine, 68, 887-904. http://dx.doi.org/10.1180/0026461046860229

Azer, M. K. \& Khalil, A. E. S. (2005). Petrological and mineralogical studies of Pan-African serpentinites at Bir Al-Edeid area, central Eastern Desert, Egypt. Journal of African Earth Sciences, 43, 525-536. http://dx.doi.org/10.1016/j.jafrearsci.2005.09.008

Barnes, I. \& O’Neil, J. R. (1969). The relationship between fluids in some fresh alpine-type ultramafics and possible modern serpentinization. Geological Society of America Bulletin, 80, 1947-1960. http://dx.doi.org/10.1130/0016-7606(1969)80[1947:TRBFIS]2.0.CO;2

Bashir, E. (2010). Geology and Geochemistry of Magnesite Deposits of Khuzdar, Balochistan, Pakistan, LAP LAMBERT Academic Publishing GmbH \& Co., ISBN: 978-3-8383-9844-0, 242p.

Bodinier, J. L. \& Godard, M. (2003). Orogenic, Ophiolitic, and Abyssal Peridotites. In: H.D. Holland, and K.K. Turekian, (exe. Eds.). Treatise on Geochemistry, 2, 103-171.

Bodinier, J. L., Garrido, C., Chanefo, I., et al. (2008). Origin of Pyroxenite-PeridotiteVeinedMantle by Refertilization Reactions: Evidence from the Ronda Peridotite (Southern Spain). Journal of Petrology, 49(5), 999-1025. http://dx.doi.org/10.1093/petrology/egn014

Bosch, D., Jamais, M., Boudier, F., et al. (2004). Deep and high-temperature hydrothermal circulation in the Oman Ophiolite -petrological and isotopic evidence. Journal of Petrology, 45(6), 1181-1208. http://dx.doi.org/10.1093/petrology/egh010 
Deer, W. R., Howie, R. A. \& Zussman, J. (1992). An Introduction to the rock-forming minerals. Longman, Essex, U. K.

Deschamps, F., Guillot, S., Godard, M., et al. (2009). In situ characterization of serpentinites from forearc mantle wedges: Timing of serpentinization and behavior of fluid-mobile elements in subduction zones. Chemical Geology, 269, 262-277. http://dx.doi.org/10.1016/j.chemgeo.2009.10.002

Dilek, Y. \& Thy, P. (2009). Island arc tholeiite to boninitic melt evolution of the Cretaceous Kizildag (Turkey) ophiolite: Model for multi-stage early arc-forearc magmatism in Tethyan subduction factories. Lithos, 113, 68-87. http://dx.doi.org/10.1016/j.lithos.2009.05.044

Dódony, I., Pósfai, M., \& Buseck, P. R. (2002). Revised structure models for antigorite: An HRTEM study. American Mineralogist, 87, 1443-1457.

Ehlers, E. G. \& Blatt, H. (1980). Petrology (Igneous, sedimentary and metamorphic). San Francisco: W.H. Freeman and Co.

Frost, B. R. \& Beard, S. (2007). On Silica Activity and Serpentinization. Journal of Petrology, 48 (7), 1351-1368. http://dx.doi.org/10.1093/petrology/egm021

Gnos, E., Khan, M., Mahmood, K., et al. (1998). Bela oceanic lithosphere assemblage and its relation to the reunion hotspot. Terra Nova, 10, 90-95. http://dx.doi.org/10.1046/j.1365-3121.1998.00173.x

Godard, M., Lagabrielle, Y., Alard, O., et al. (2008). Geochemistry of the highly depleted peridotites drilled at ODP Sites 1272 and 1274 (Fifteen-Twenty Fracture Zone, Mid-Atlantic Ridge): Implications for mantle dynamics beneath a slow spreading ridge. Earth and Planetary Science Letters, 267, 410-425. http://dx.doi.org/10.1016/j.epsl.2007.11.058

Khan, M., Gnos, E., Mahmood, K., et al. (1999). Metamorphic rocks associated with Bela Ophiolite, Pakistan. Acta Mineralogica Pakistanica, 10, 37-44.

Li, X. P., Rahn, I. M. \& Bucher, K. (2004). Serpentinites of the Zermatt-Saas ophiolite complex and their texture evolution. J. metamorphic Geol., 22,159-177.

Melcher, F., Meisel T., Puhl J. et al. (2002). Petrogenesis and geotectonic setting of ultramafic rocks in the Eastern Alps: constraints from geochemistry. Lithos, 65, 69-112. http://dx.doi.org/10.1016/S0024-4937(02)00161-5

Moody, J. B. (1976). Serpentinization: A review. Lithos, 9(2), 25-138. http://dx.doi.org/10.1016/0024-4937(76)90030-X

Nicolas, A. (1989). Structures of ophiolites and dynamics of oceanic lithosphere. Dordrecht: Kluwer Academic $\mathrm{Pb}$. http://dx.doi.org/10.1007/978-94-009-2374-4

Özkan, Y. Z. (1983-84). Effects of metamorphism in the Guleman ophiolite. Bulletin of the mineral research and exploration, 101-102, 1-11. [Online] Available at: http://www.mta.gov.tr/english/dergi/dergi_pdf/101-102/1.pdf

Page, N. J. (1968). Chemical differences among the serpentine polymorphs. The American Mineralogist, 53, 201-215. [Online] Available at: http://www.minsocam.org/ammin/AM53/AM53_201.pdf

Palandri, J. L. \& Reed, M. H. (2004). Geochemical models of metasomatism in ultramafic systems: Serpentinization, rodingitization, and sea floor carbonate chimney precipitation. Geochimica et Cosmochimica Acta, 68 (5), 1115-1133. http://dx.doi.org/10.1016/j.gca.2003.08.006

Palme, H. \& O’Neill, H. St. C. (2003). Cosmochemical Estimates of Mantle Composition. In: H.D. Holland, and K.K. Turekian, (exe. Eds.). Treatise on Geochemistry, 2, 1-38.

Pearce, J. A., Lippard, S. J. \& Roberts, S. (1994). Characteristics and tectonic significance of supra-subduction zone ophiolites. In: B.P. Kokelaar, and M.F. Howels, (Eds.), Marginal Basin Geology: volcanic and associated sedimentary and tectonic processes in modern and ancient marginal basins. Geol. Soc. London Sp. Publication, $16,77-94$.

Piccardo, G. B., Vannucci, R., \& Guarnieri, L. (2009). Evolution of the lithospheric mantle an extensional setting: Insight from ophiolitic peridotites. Lithosphere, 1/2, 81-87. http://dx.doi.org/10.1130/L30.1

Raymond, L. A. (2002). The study of Igneous, sedimentary and metamorphic rocks. Mc.Graw Hills.

Robinson Jr., G. R., Van Gosen, B. S., Nora, K. et al. (2006). Ultramafic-hosted Talc-Magnesite deposits. This presentation on the geology of ultramafic-hosted talc-magnesite deposits was given at the $42^{\text {nd }}$ Forum on the Geology of Industrial Minerals, May 7-13, 2006, Asheville, NC (USA). 
Sano, S. \& Kimura, J. (2007). Clinopyroxene REE Geochemistry of the Red Hills Peridotite, New Zealand: Interpretation of Magmatic Processes in the Upper Mantle and in the MohoTransition Zone. Journal of Petrology, 48(1), 113-139. http://dx.doi.org/10.1093/petrology/eg1056

Shervais, J. W., Kolesar, P. \& Andreasen, K. (2005). A Field and Chemical Study of Serpentinization -Stonyford, California: Chemical Flux and Mass Balance. International Geology Review, 47, 1-23. http://dx.doi.org/10.2747/0020-6814.47.1.1

Sheth, H. C. (2008). Do major oxide tectonic discrimination diagrams work? Evaluating new log-ratio and discriminant-analysis-based diagrams with Indian Ocean mafic volcanics and Asian ophiolites. Terra Nova, 20, 229-236. http://dx.doi.org/10.1111/j.1365-3121.2008.00811.x

Simandl, G. J. \& Ogden, D. (1999). Ultramafic-hosted talc-magnesite. In: G.J. Simandl, Z.D. Hora, and D.V. Lefebure, (Eds.). Selected British Columbia mineral deposit profiles, V. 3, Industrial Minerals: British Columbia Ministry of Energy and Mines.

Sleep, N. H., Meibom, A., Th. Fridriksson, Coleman, R. G. et al. (2004). $\mathrm{H}_{2}$-rich fluids from serpentinization: Geochemical and biotic implications. PNAS, 35(101), 12818-12823. http://dx.doi.org/10.1073/pnas.0405289101

Snyder, G. T., Savov, I. P., \& Muramatsu, Y. (2005). Iodine and boron in Mariana serpentinite mud volcanoes (ODP Legs 125 and 195): In M. Shinohara, M.H. Salisbury, and C. Richter, (Eds.), implications for forearc processes and subduction recycling. Proc. ODP, Sci. Results, 195, 1-18.

Yalcin, H. \& Bozkaya, O. (2004). Ultramafic-Rock-Hosted vein Sepiolite occurrences in the Ankara Ophiolitic Mélange, Central Anatolia, Turkey. Clays and Clay Minerals, 52 (2), 227-239.

Yaliniz, M. K., Floyd, P. A. \& Goncuoglu, M. C. (1996). Supra-subduction zone ophiolites of Central Anatolia: geochemical evidence from the Sarikaraman Ophiolite, Aksaray, Turkey. Mineralogical Magazine, 60, 697-710. [Online] Available at: http://minmag.geoscienceworld.org/cgi/content/abstract/60/5/697

Yingqian. X., Shuhab, K. \& Khalid, M. (2008). Whole Rock Geochemistry of Lavas from Bela Ophiolite, Western Pakistan. Paper No. 200-1, Joint Meeting of The GSA, Soil Science Society of America, American Society of Agronomy, Crop Science Society of America, Gulf Coast Association of Geological Societies with the Gulf Coast Section of SEPM.

Table 1. Mineralogical data (\%) of selected host rock samples obtained by XRD analysis

\begin{tabular}{|l|l|l|l|l|l|l|l|l|l|l|}
\hline $\begin{array}{l}\text { Samp } \\
\text { le No }\end{array}$ & $\begin{array}{l}\text { Oliv-i } \\
\text { ne }\end{array}$ & $\begin{array}{l}\text { Ensta-t } \\
\text { ite }\end{array}$ & $\begin{array}{l}\text { Esse-ne } \\
\text { ite }\end{array}$ & $\begin{array}{l}\text { Hypers-th } \\
\text { ene }\end{array}$ & $\begin{array}{l}\text { Heden-ber } \\
\text { gite }\end{array}$ & $\begin{array}{l}\text { Diop-si } \\
\text { de }\end{array}$ & $\begin{array}{l}\text { Au-g } \\
\text { ite }\end{array}$ & $\begin{array}{l}\text { Anti-go } \\
\text { rite }\end{array}$ & $\begin{array}{l}\text { Lizar-d } \\
\text { ite }\end{array}$ & $\begin{array}{l}\text { Chyr-so } \\
\text { tile }\end{array}$ \\
\hline GG2 & & & 11.0 & & & 10.8 & 24.9 & & 37.0 & \\
\hline UE3 & 2.5 & 26.4 & & & 9.9 & & & 53.1 & & \\
\hline KC1 & 8.6 & 47.1 & & & & & & 52.9 & & \\
\hline KE1 & 29.8 & & & 45.2 & & & & 25.0 & & \\
\hline PK1 & 8.1 & 14.0 & & & & & & & 64.0 & \\
\hline PE1 & & & & & & & & 100.0 & & \\
\hline BN2 & & 18.1 & & 35.1 & & & 8.6 & & & 14.7 \\
\hline BE2 & 3.0 & 15.6 & 8.6 & & & & & & 36.4 & 14.0 \\
\hline BL1 & 2.0 & 7.6 & 4.0 & & & & & 62.4 & 23.0 & \\
\hline BS1 & 27.8 & & & & & 8.1 & 5.5 & 26.3 & & \\
\hline SG1 & & 60.5 & & & & & & 39.5 & & \\
\hline GD1 & & & & & & & & 100.0 & & \\
\hline
\end{tabular}




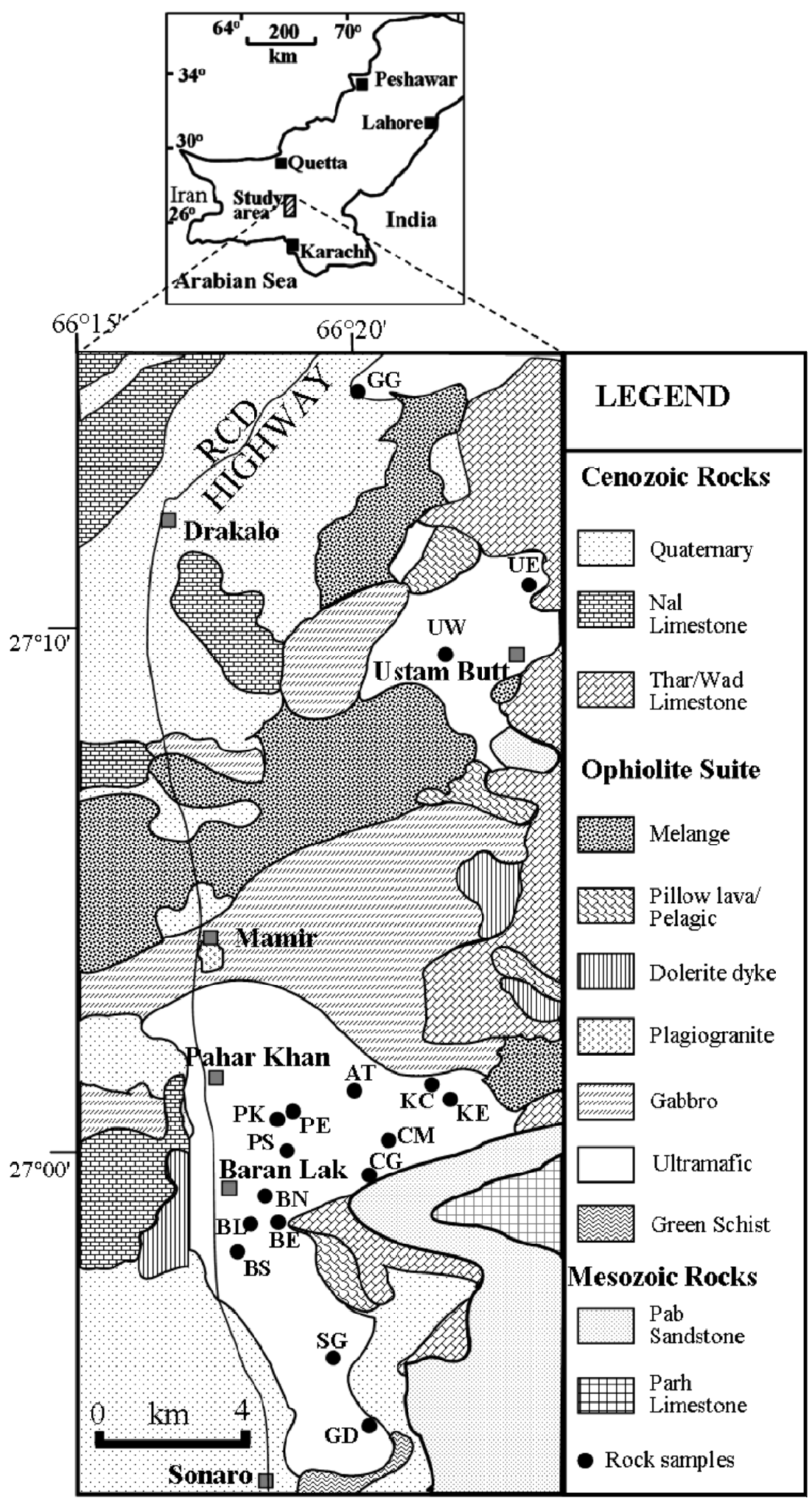

Figure 1. Geological map of study area showing sampling sites (modified after Bashir, 2010) 


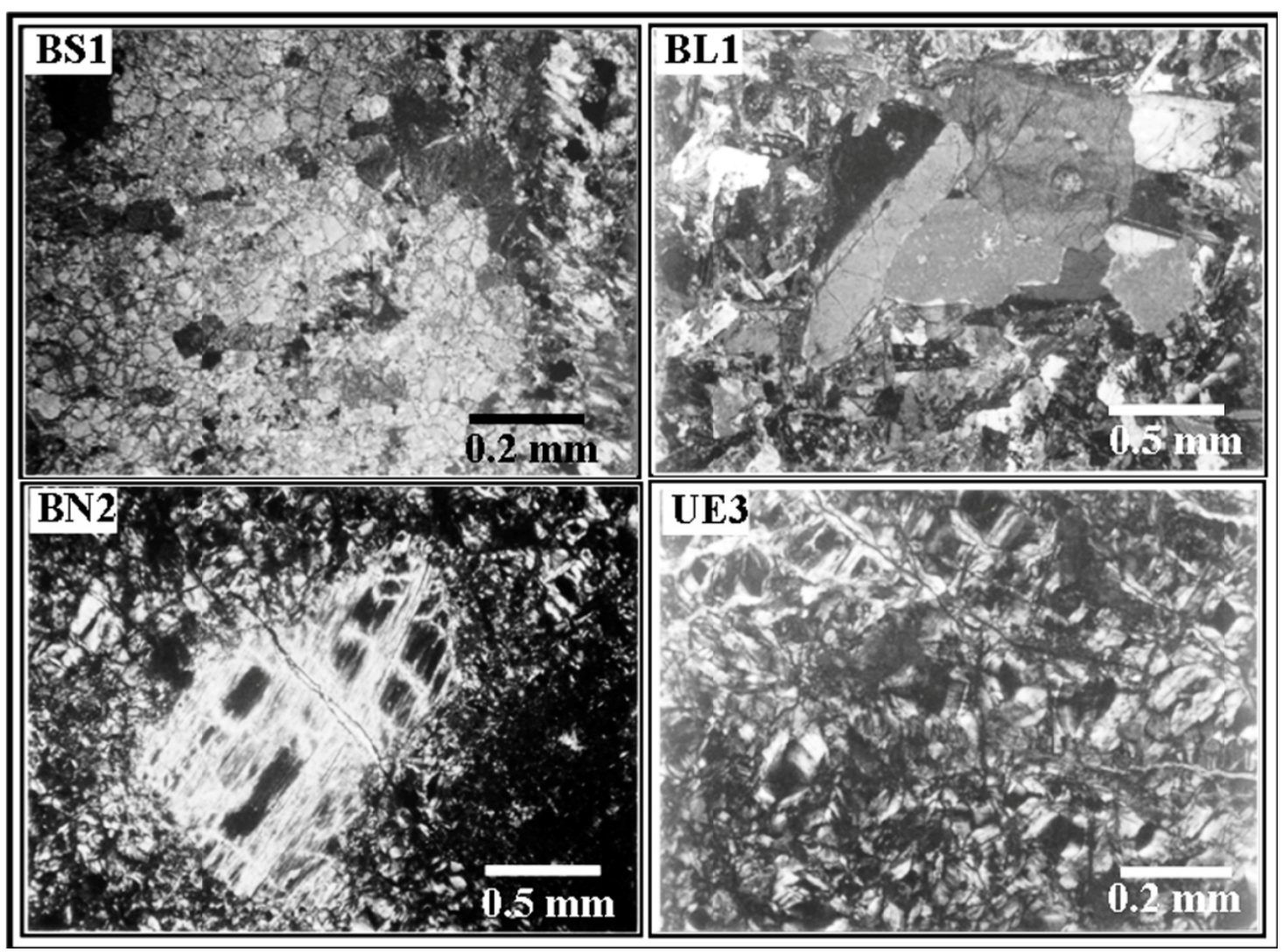

Figure 2. Photomicrographs of serpentinized rocks of the study area. Sample numbers are marked on left top. All are in crossed nicols

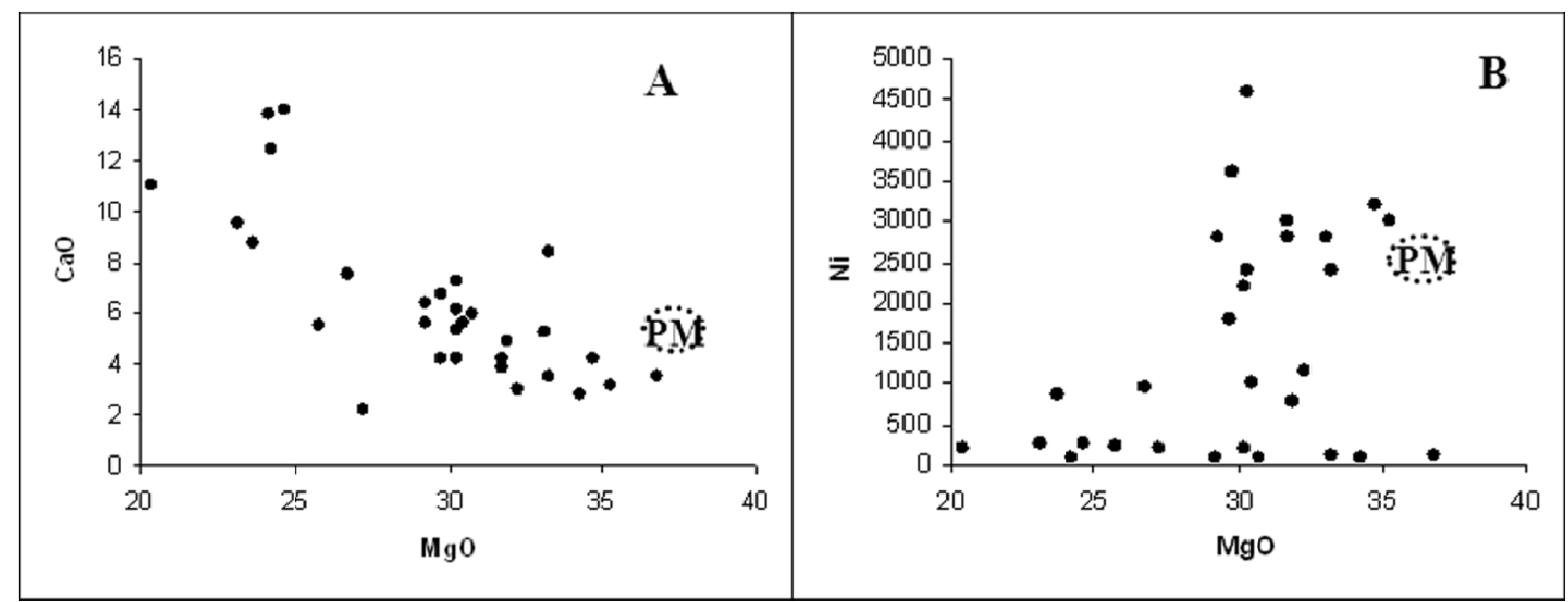

Figure 3. (A) Relation of $\mathrm{MgO}$ vs. $\mathrm{CaO}$; (B) $\mathrm{MgO}$ vs. Ni contents in the primitive mantle and studied rocks 

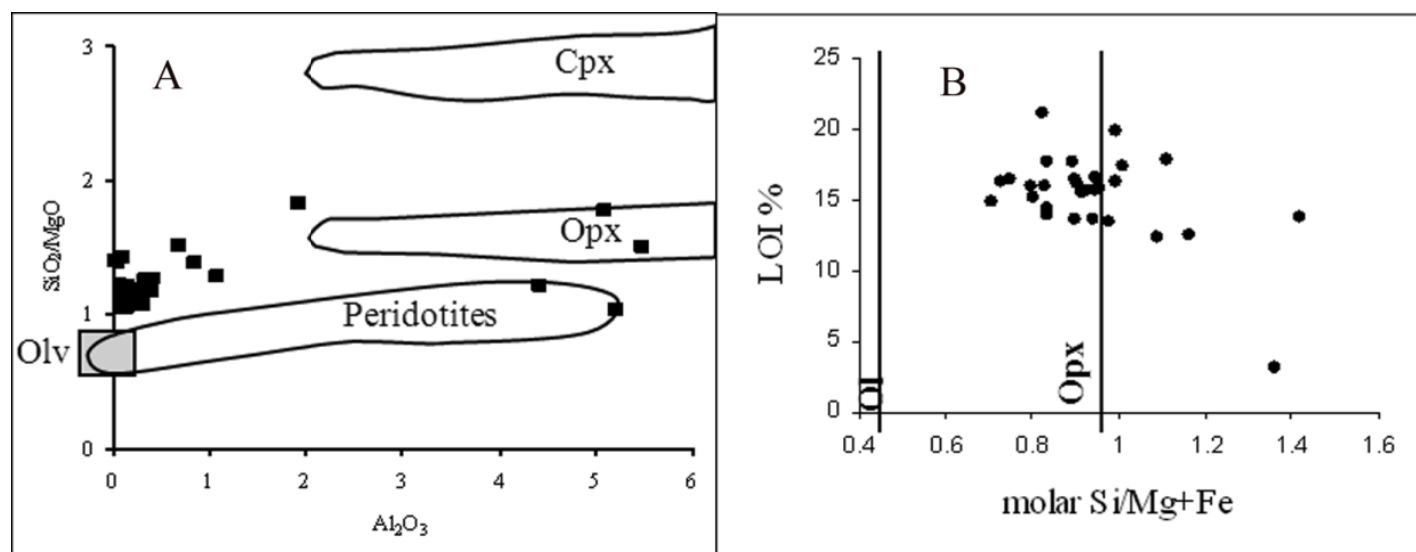

Figure 4. (A) $\mathrm{SiO}_{2} / \mathrm{MgO}$ versus $\mathrm{Al}_{2} \mathrm{O}_{3}$ (anhydrous wt. \%) represents ultramafic rocks from study area (modified after Bodinier and Godard, 2003); (B) Molar ratio Si/Mg+Fe vs. LOI reveals mobility of elements and serpentinization (fields after Melchar et al., 2002)

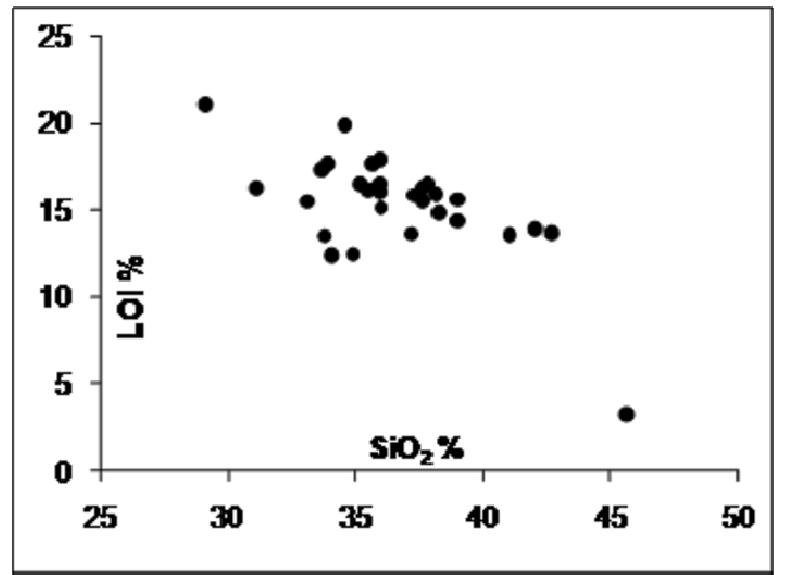

Figure 5. $\mathrm{SiO}_{2}$-LOI plot showing variable degree of serpentinization in the rocks of the study area

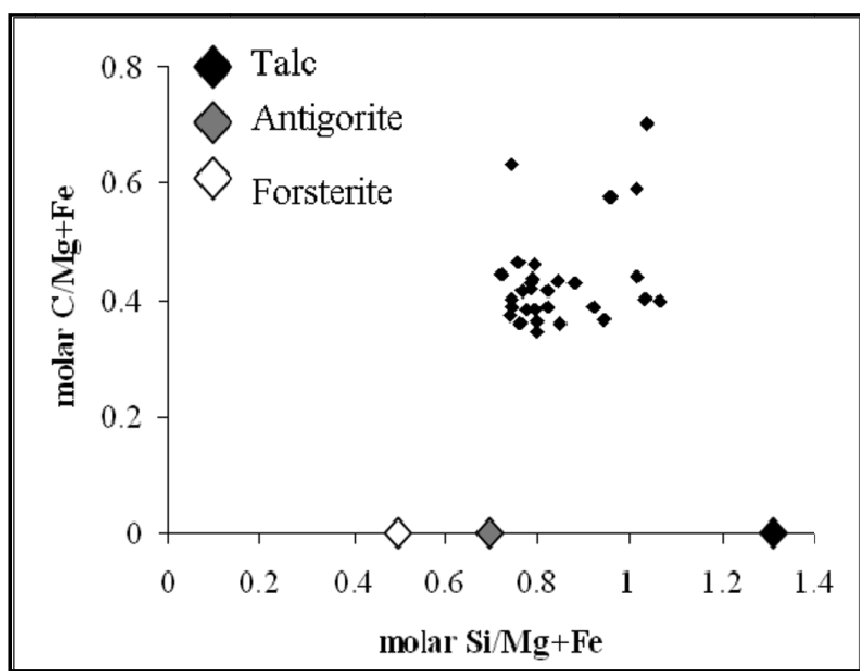

Figure 6. Molar ratio diagram displays alteration path and characteristic mineral assemblages of serpentines and carbonates (field after Robinson et al., 2006) 

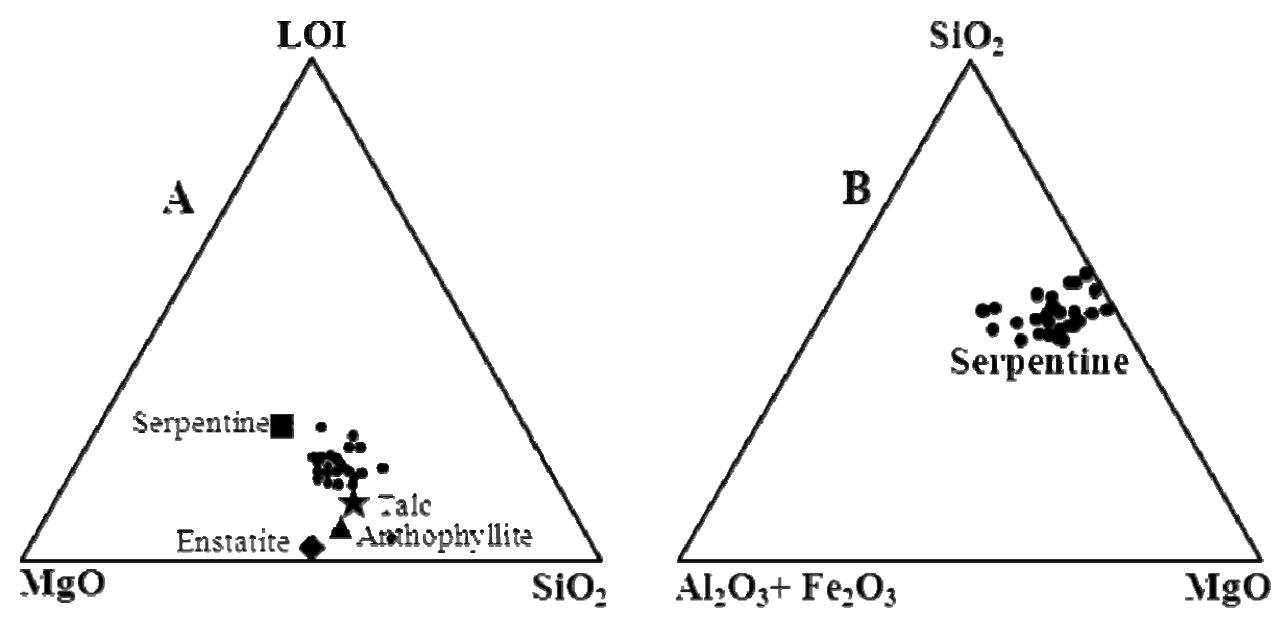

Figure 7. Average whole rock chemistry of ultramafic minerals along with samples of study area in: (A) $\mathrm{MgO}-\mathrm{SiO}_{2}$-LOI system (field after Ehlers and Blatt, 1980); (B) $\mathrm{Al}_{2} \mathrm{O}_{3}+\mathrm{Fe}_{2} \mathrm{O}_{3}-\mathrm{SiO}_{2}-\mathrm{MgO}$ (field after Yalcin and Bozkaya, 2004)

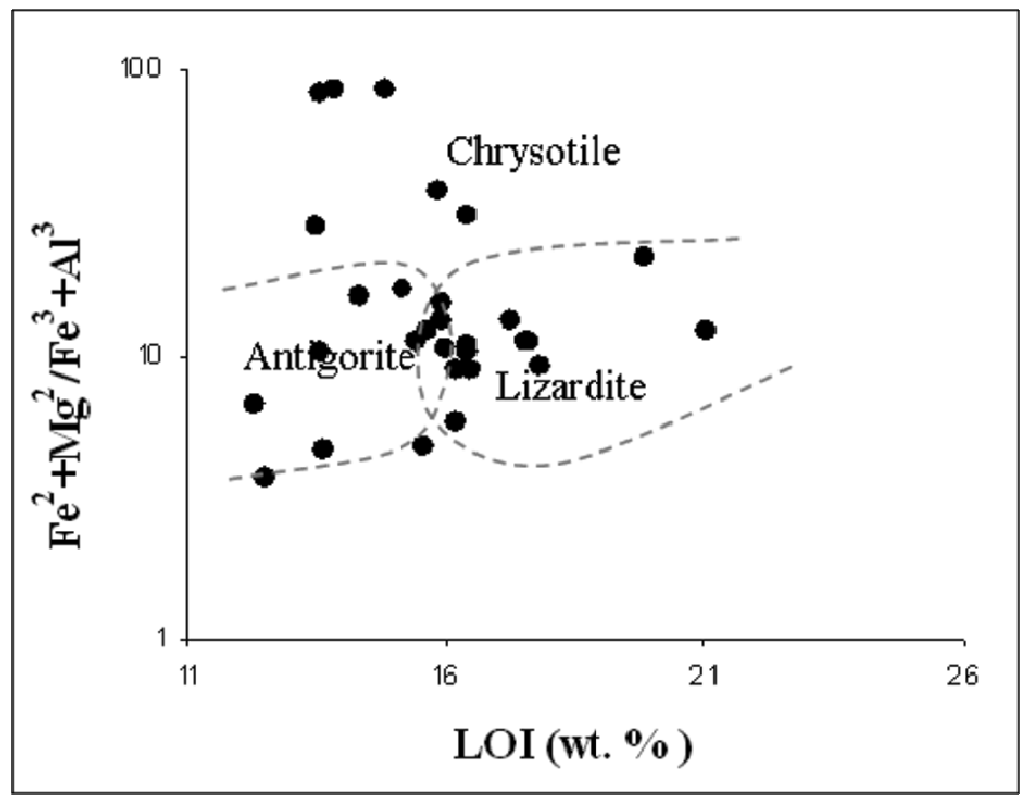

Figure $8 . \mathrm{Fe}^{2+}+\mathrm{Mg}^{2+} / \mathrm{Fe}^{3+}+\mathrm{Al}^{3+}$ vs. LOI relationship between minerals of serpentine group. Approximate boundaries between minerals are marked after Page (1968) 